\title{
The Potential Impacts of Hydraulic Fracturing on Agriculture
}

Beng Ong ${ }^{1}$, Ph.D.

\begin{abstract}
Hydraulic fracturing (or "fracking") is a method of extracting oil and natural gas trapped in deep rock layers underground by pumping water, sand, and other chemicals/additives at high pressures into a well drilled vertically, and then horizontally into the rocks. Advocates of fracking in U.S. have skillfully positioned domestic natural gas as a sensible alternative energy to the country's goals of reducing carbon emissions and dependence on foreign oil, while simultaneously creating jobs locally. Opponents to fracking, however, alleged that the process pollutes the air, contaminates the soil and water, particularly in farming/rural communities. Due to page limitson this paper, we discussed only the potential impacts of hydraulic fracturing on water, and consequently, agriculture. Any impact on agriculture extends beyond the perimeter of a farm or plot of rural land where fracking operations occur. Fruits, vegetables, dairy, and meats from an impacted farming region may be shipped to other parts of the country, or even internationally. Fracking challenges stakeholders to confront the trade-offs between economic development and public health/safety; thus multiple viewpoints and issues were raised.
\end{abstract}

Keywords: Hydraulic Fracking; Environmental Sustainability; Water Contamination; Agriculture vs. Energy; Shale Gas.

\section{Introduction}

Hydraulic fracturing, often referred to as "fracking", is a method of extracting oil and natural gas trapped in deep rock layers underground by pumping water, sand, and other chemicals/additives at high pressures into a well drilled vertically, and then horizontally into the rocks. The fluids and pressure combined to create fractures or cracks within the rock (or shale - a common fine-grained sedimentary rock), and the gas/oil is released from the fractures. The sand serves to prevent the fractures from collapsing and re-trapping the natural gas in the shale. The gas is also known as shale gas (http://www.shaletec.org/). With increasing global concerns over climate change and greenhouse gas emissions, natural gas appears to be the timely source of energy as it is a relatively clean-burning fossil fuel compared to petroleum and coal. For example, generating electricity with natural gas leads to approximately 50 percent less carbon dioxide emissions than coal-based power generation, and 30 percent less than oil-based generation (Smith, 2012). Abundant, cheap natural gas in America has benefited consumers in the form of lower utility bills as power plants opted for natural gas instead coal for energy generation (McElroy \& Lu, 2013). Perhaps, the benefits stretch further as producers, manufacturers, and just about any business (including farmers) that could 
switch to natural gas enjoy more energy cost savings which may translate to flat or lower prices in their outputs. Apart of using natural gas to generate electricity, city-owned buses/automobiles, and taxis with city permits could be modified to run on domestically produced compressed natural gas to help reduce carbon emissions.

Opponents to fracking, however, alleged that the process/operations led to air pollution, soil and water contaminations, particularly in farming communities. Because of the shale locations, flat lands in rural areas, and farmers tempted by royalties from gas drilling leases on their farms, fracking and farming tend to share the same locales. Proponents of domestic drilling for oil and gas cited the nation's (USA in the context of this paper) energy security priority (i.e., less dependent on oil imports from the Middle-East), and contributions to the local and regional economy (e.g., job creations) as justifications for hydraulic fracturing. An even larger economic opportunity may lie in exports of natural gas to Europe and Asia where prices are much higher than in the U.S. (McElroy \& Lu, 2013). Japan needs alternative energy sources to produce electricity in the wake of the Fukushima earthquake and plant shut downs. China wants cleaner burning fuels or cleaner energy to reduce air pollution in its cities. The arguments and counterpoints presented by the various constituents on the fracking issue in U.S. merit discussion as the stakes are high. It is a debate on whether producing food or energy deserves higher priority. Fracking challenges stakeholders to confront the trade-offs between economic development and public health/safety. In this paper, we chose to discuss the potential impacts of hydraulic fracturing on agriculture because any impact on agriculture extends beyond the perimeter of a farm or plot of rural land where fracking operations occur. Fruits, vegetables, dairy, and meats from an impacted farming region may be shipped to other parts of the country, or even internationally.

\section{Water Contamination}

We begin with a discussion of water contamination as the issue draws the most controversy. Public awareness is increasingly heightened by media coverage with anecdotes of people and farm animals that died prematurely or became sick near fracking wells. These incidents allegedly occurred within a few years after fracking operations started in the neighborhood. What garners even more public attention is when environmental groups question the safety of a town's or city's drinking water. Politicians and law makers are more likely to act on wide public fears of unsafe drinking water. Case in point, New York has enforced a statewide fracking moratorium since 2008 while the State's Department of Environmental Conservation studies the impact of fracking on its aquifers and watersheds (McKinley, 2013).

Local water quality may be compromised at several stages of shale gas extraction (Smith, 2012). Fracking fluids injected down the wells under high pressure to fracture the shale consist mainly of water $(90+\%)$, sand or other proppant $(9 \%)$ to keep the fractures open, and additives (less than 1\%) which could include lubricants, biocides, rust inhibitors, solvents, foaming agents, and emulsifiers (Royte, 2012; Smith, 2012). These chemicals could be a variety of acids and alcohols, and/or compounds containing benzene, ammonia, and/or sodium (- see http://marcellusdrilling.com/2010/06/list-of-78chemicals-used-in-hydraulic-fracturing-fluid-in-pennsylvania/). The amounts of additives used vary by drillers and sites, but do not need to be disclosed to state or federal agencies. 
Hydraulic fracturing is exempt from U.S. Safe Drinking Water Act (http://water.epa.gov/type/groundwater/uic/class2/hydraulicfracturing/wells hydroreg.cfm).

Drilling companies do not want to fully disclose the contents of their fracking fluids for proprietary reasons. The concoction of chemicals used in fracking is regarded as a trade secret.

\section{Underground Contamination}

Considering the four to seven million gallons of water needed to frack a single well, the 0.4 percent to less than 1 percent of chemicals in the fracking fluid could equate to 40,000 gallons of additives per well (Royte, 2012; Smith, 2012). An article in the British Columbia Medical Journal noted that an analysis of 353 of these chemicals found that more than 75 percent could have respiratory, gastrointestinal, dermatological, and ocular effects; 40 to 50 percent could be neuro-, immune-, and nephrotoxic; 37 percent could be endocrine distuptors; and 25 percent could be carcinogenic (Benusic, 2013). Linking illness in humans and animals living near a fracking site to specific chemicals would be difficult when drillers do not have to fully disclose all the chemicals and concentrations used. Exemption from disclosure appears to have lowered energy companies' liability risks. Smith (2012), however, pointed out that many of the chemicals used in fracking fluids are commonly encountered in household detergents, food additives, and swimming pool treatments, and that a movement is underway to use greener fracking fluids, and to use less chemicals.

Contamination of ground water could occur through leaky well casings. The oil industry's disclosed casing failure rate was averaging 6 to 10 percent (Aiello, 2013). A published peer-reviewed study by Duke University researchers found measurably high levels of methane in well drinking water collected near hydraulic fracking sites. In 85 percent of the samples, methane levels were 17 times higher on average in wells located within one kilometer of active fracking sites (Lafrance, 2011). While methane in the drinking water is not hazardous to ingest, ignitable tap water can be a safety and fire hazard (Benusic, 2013). The scientists also found higher concentrations of ethane and propane in drinking water wells less than six-tenths of a mile from shale gas drilling (Thompson, 2012).However, the study did not find contamination in the drinking well water from the fracking fluids. One of the researchers argues that flaws in the concrete seal would allow gas to migrate while still preventing leakage of fracking fluid. Then there is the question of whether leaks and contamination (if any) were known or reported to appropriate government agencies. It is unclear whether groundwater near a fracking operation is monitored (and for how long after operations have ceased), and who or which organization would be doing the monitoring. Testing and monitoring would involve guesswork as to which chemical compounds to look for since the contents of fracking fluids are not disclosed.

The estimated 30 percent of injected fracking fluids that stayed down in the shale fractures could, over time, flow upwards through fissures and cracks in the shale and contaminate the aquifer above. This risk is very minimal as a typical well (in the Marcellus Shale) is 5,000 feet deep while the aquifers are less than 1,000 feet deep (Smith, 2012). Furthermore, there is no pressure in abandoned wells to force the upward flow of remaining fracturing fluid into the fissures above. However, a report by researchers at Duke University, published in the Proceedings of the National Academy of Sciences, said a 
chemical analysis of 426 shallow groundwater samples found matches with brine found in rock more than one mile (1.2 kilometers) deep, suggesting possible natural paths and fissures that could let gas or water flow up into the aquifer after drilling (Drejam, 2012).

\section{Surface Contamination}

Another potential water contamination is when fracking fluids flow back up to the surface (Royte, 2012). To collect the gas and/or oil after fracturing the shale, the pressure in the well is decreased to allow the fracturing fluids and possibly naturally occurring fluids and substances held in the rocks to flow back to the surface (Lafrance, 2011). The liquid could be tainted with naturally occurring deep-earth compounds such as sodium, chloride, bromide, arsenic, barium, uranium, radium, and radon. Radioactive material above background levels has been detected in air, soil, and water at or near gas drilling sites (Royte, 2012).

Spent fracking fluids could contaminate groundwater as a result of surface spills and/or through improper disposal of the wastewater. On the latter case, after being alerted by a farmer and community activist, The Central Valley Regional Water Quality Control Board investigated the discharge of fracking waste to an oilfield sump near almond orchards in Shafter, California. The petroleum subsidiary company had permission to discharge drilling mud and boring waste to the sump, but the Regional Board found the fluid laced with boron, benzene, salts, and a cocktail of notorious chemicals related to gasoline and diesel. The chemicals appeared to have been used in hydraulic fracturing for oil (Grossi, 2013).

Some gas drillers sent the wastewater to municipal sewage plants which are not designed to treat/remove toxic chemicals in the fluids (if the plants knew what to treat/remove in the first place). Removing dissolved salts from the high salt content in the fluids requires expensive distillation or reverse-osmosis (Schmidt, 2013). Partially treated fracking wastewater may have been discharged into rivers which, in turn, could become drinking and irrigation water for communities downstream.

Some wastewater in one State is trucked to another State for disposal by injecting the water underground. However, small earthquakes linked to underground wastewater disposal activities have curtailed this disposal method (Schmidt, 2013). Trucking fracked wastewater to a private or municipal treatment plant, or to an underground injection facility heightens the risks of risk of spills, traffic accidents, and contaminations along the journey.

Due to insatiable global appetite for cheap natural gas, fracking in U.S. is increasing, and the amount of wastewater being generated is going up exponentially. Gas/oil drillers are increasingly re-using some of the spent fluids. But re-use currently involves first storing the fluids in man-made holding ponds, and diluting the fluid with millions of gallons of fresh water (Bullis, 2013). There could be a wait time for the heavier particulates (such as mud, sand, etc.) to settle to the bottom of the pond before the water is reloaded into trucks and transported to the next well. In the process, the risks of spills and leaks are omnipresent. Scientists are working on new technology such as membrane distillation which combines heat and decreased pressure to vaporize water and using membranes to separate pure water vapor from salt water (Bullis, 2013). The technology could remove the need to dilute wastewater, or transport it for treatment or disposal. However, this 
new technology may not be cost-effective if the wastewater was not too salty, and could be treated with existing technology (Bullis, 2013).

Even re-used water would eventually not be re-usable anymore and has to be disposed, or treated. A common method of fracking fluid disposal is to hold the wastewater in plastic lined evaporation ponds or isolated pits. However, the use of pit liners has not been entirely successful in preventing leaks. The Denver Post cited 31 reported spills (in the State of Colorado) of produced water due to pit leaks from January 2008 to mid-June 2010 (Hubbard, 2010). In that time period, there were 182 reported spills in Colorado that impacted groundwater; 82 reported spills that impacted surface water; and 10 spills that impacted both (see table in Hubbard, 2010 article).

Natural disasters, namely, floods add to the potential for surface water contamination. In the September 2013 floods in Colorado, floodwaters in Weld County (where there are 20,000 oil and gas wells) surged into drilling centers and overflowed wells, broke pipes, and swept oil tanks off their foundations (Healy, 2013). The Colorado Oil and Gas Conservation Commission estimated approximately 35,000 gallons, or 882 barrels of oil and condensate (hydrocarbons in a mixture of liquid-gas state) spilled into the rivers and floodwaters. Proponents of oil/gas drilling argued that the spill was very small compared to Exxon Valdez spill that exceeded 257,000 barrels (Richardson, 2013). Environmental groups argued that fracking fluids in the evaporation pits would have contaminated the floodwaters and over-flowed rivers.

\section{Water Consumption}

Fracking also consumes millions of gallons of water. One source stated that four million gallons of water are typically required to fracture-treat a single horizontal well (Smith, 2012). In drought-prone regions in Texas and California where water is a precious resource for agriculture, vast water use in fracking could deplete water tables, and drive up the price of water. Agricultural water districts from Modesto to Maricopa, California were alarmed by oil and gas companies' willingness to pay three times the rate these districts expected to pay (Aiello, 2013b). A study commissioned by Texas Water Development Board found that in a five-county area that includes Dimmit, fracking reduces the amount of water in the Carrizo-Wilcox Aquifer by the equivalent of one-third of the aquifer's recharge (Galbraith, 2013). As a result some of the land in Carrizo Springs, Texas (which sits above the Eagle Ford Shale) is sometimes too dry to grow crops. A University of Texas study published in 2013 found that the amount of water used statewide for fracking more than doubled between 2008 and 2011. The amount is expected to increase before leveling off in the 2020s. Exacerbating water depletion is the growing number of landowners that construct new water wells to sell groundwater to oil and gas drillers (Galbraith, 2013).

In other parts of the country, operators may draw water from a small stream for fracking. This would create a strain on plants and wildlife within the immediate ecosystem (Smith, 2012). Farmers may be forced to reduce their water use, or have some of the intended irrigation water diverted back to the small stream for plants and wildlife.

As noted earlier in this paper, fracking operators have increasingly re-used the produced water; sometimes in the pretext of being green. Cost maybe the true reason for greater water re-use. Treating produced water sufficiently to remove contaminants can be very 
expensive (Smith, 2012). As indicated on Altela Inc.'s website (http://www.altelainc.com/applications/detail/oil-and-gas-industry-produced-water ), the cost of disposing oil/gas produced water in the U.S. ranges from a low of $\$ 0.002$ per gallon $(\$ 0.08 /$ barrel of wastewater) to a high of $\$ 0.30$ a gallon $(\$ 12.00 / \mathrm{barrel})$. Fresh water for agricultural irrigation can be as low as $\$ 0.0001$ per gallon $(\$ 0.004 /$ barrel) and municipal drinking water costs in the range of $\$ 0.001$ per gallon $(\$ 0.04 /$ barrel $)$. However, in places where municipal water is not available, fracking demands have pushed the price of fresh water sky high. A farm owner in Carrizo Springs, Texas has been offered as much as 70 cents per barrel of water he pumps from an aquifer beneath his land (Carroll, 2011). Thus, the impact of vast water use in fracking on agriculture, in the short run, could be reduced acreage farmed and higher food prices just from the increased cost of water alone. The long run impact could be reduced acreage farmed and farm yields due to the shortage of water, and/or farmers offsetting their reduced farm incomes with sales of water to fracking operators.

To address these price and water shortage challenges, some companies are experimenting with the use of brackish water, an abundant underground resource in Texas. But the water contains more salts than fresh water does, and the reservoirs may be deeper and more expensive to tap (Galbraith, 2013). A few companies are buying treated city sewage water for use in oil fields. Water-free fracking is another option. Gasfrac, a Canadian company that uses propane rather than water in fracking, drilled a well last month in Dimmit County, Texas (Galbraith, 2013). With wastewater hauling fees of $\$ 3$ to $\$ 6$ per barrel in the Eagle Ford Shale region (Schaefer, 2012), the business opportunities are ripe for the right companies with the right technologies to setup on-site facilities to perform fracking fluids treatments, and water recovery for reuse. Whether on-site treatments and re-use of produced water would lessen surface contamination risks remains to be seen. On site wastewater treatment could also lead to air pollution and soil contamination from air-borne dissolved solids after the wastewater has evaporated, or improper/sloppy disposal of waste residue.

\section{Other Environmental, Economic, and Social Impacts}

At almost every stage of developing and operating an oil or gas well, chemicals and compounds can be introduced into the environment. Radioactive material above background levels and volatile organic compounds including benzene, toluene, ethylene and xylene, have been detected in air, soil, and water at or near gas-drilling sites. Fracking a single well may require 800 truck trips if fresh water for fracking has to be hauled to the drill pad from a municipal water supply station (Smith, 2012). Hauling wastewater out to discharge sites or holding ponds could result in additional truck trips. Apart from the dust, noise, and soil compaction that resulted from frequent heavy-duty truck traffic, emissions from these trucks as well as large generators and compressors at well sites form ground-level ozone (Anonymous, Food \& Water Watch, 2012).

Awareness of potential soil and water contaminations from fracking could trigger consumers' reluctance to buy/consume meat, milk, and other produce that originated from farms near fracking operations. A drill pad on the horizon of a farm could severely erode the marketability of the farm's products whether the farm is supplying to high end or organic restaurants, or operating a "pick-your-own fruit" orchard, or selling farm-work-vacation experience. Park Slope Food Co-op in Brooklyn 
(with 16,200 members) buys $\$ 4$ million annually in direct sales from local farms (Royte, 2012). The founder of "Chefs for the Marcellus" remarked that she keeps a map of the Marcellus Shale wells and suppliers' farm locations. Abundant natural gas in the U.S. could lead to lower synthetic fertilizer costs. However, organic farmers would not be helped by cheaper synthetic fertilizers.

Preserving brand confidence alone is sufficient to prompt wary farmers to seek land away from the Marcellus Shale. The outward migration of farmers from the region could raise prices of good farmland, and devalue the price of land in the Marcellus. Lower prices entice oil/gas investors to buy up cheaper farmland, take advantage of favorable "farm rate" tax breaks, and drill, if there is no ban on fracking in that town/city, or State (Royte, 2012).

Any environmental degradation to the soil, aquifer, or air due to fracking does not stop at the boundary of a farm. The adjacent farmers that turned down (or did not receive any) frackers' royalties offers may suffer the negative impacts of fracking. Even farmers with gas leases may benefit only for a short term. Perceived or real ecological damage from fracking may not be easily repaired. Ag insurance companies have started to exclude damages related to fracking from the insurance coverage (Royte, 2012).

\section{Conclusion}

Hydraulic fracturing operations have the potential to adversely impact agriculture, particularly small farms, and the rural communities. Large farms are less likely to be tempted by short term incomes from gas leases, or sale of water because these owners have greater access to capital, and their cash flow management better able to weather the lean years. Large farms have vast water needs themselves, and operate with higher efficiencies where a drill pad or two on the farm coupled with access roads and pipelines would have hampered big farms' supply chain and farming efficiencies.

With growing consumer demand towards organic foods which small, niche, local farms could more creditably and sustainably deliver than mega farms, perceived or real contamination of water or air in the growing region could really hurt small farmers. Without deep pockets for prolonged lawsuits against oil or gas investors, or for environmental clean-ups, these farmers may lose their farms/livelihoods, move elsewhere, or keep quiet on the contamination. The wider impact of fracking will be increased food prices for consumers due to substantial competition for fresh/clean water, and reduced farm yields.

Supporters of fracking could argue that if fracking fluids are so toxic and contaminations are that ubiquitous, then why aren't we reading or hearing more about farm animals dying in large numbers, or high incidence of human illness in fracking communities. Perhaps, oil/gas producers' settlements with farmers and residents affected by fracking have included gag orders (Aiello, 2013) so that additional residents are not alerted to opportunities to proceed with their own lawsuits. Farmers who have gas leases may fear retribution from community members that did not have gas leases; others may fear getting sued under "food disparagement" laws, or sued by an oil/gas company for defamation (Royte, 2012). For these reasons, it is challenging to educate prospective future fracking lessors, and to create public awareness on the risks from fracking. Without pre-fracking measurements of chemical contents in soil, air, and water, causeand-effect links of fracking cannot be established scientifically. Furthermore, without 
mandated disclosure of chemicals, concentrations, and quantities used in fracking, monitoring agencies or parties may not know what contaminants to test for in postfracking soil, air, and water samples. It would be easy to blame the toxins found in the soil, groundwater, or air on a landowner's use of pesticides, fertilizers, or farm equipment (Royte, 2012).

Oil and gas investors may be transient corporations and limited liability companies that could dissolve their corporations/companies once they are done with fracking operations in a particular region/state. Cities may not have the financial ability to pay the huge costs of remediation 5 to 10 years later. Governments and politicians need to conduct more long-term accurate risk assessments; rather than prioritize economic gains over public health, food safety, and environmental sustainability. With EU's urgency to explore fracking and reduce its reliance on Russian natural gas due to the Ukraine crisis (Cohen, 2014), the clash over fracking for energy supply versus environmental sustainability will soon attain global prominence.

\section{References}

Aiello, D. (2013), “CA farmer warns: 'Don't trust oil industry, state or courts' to protect water' ", Examiner.com, May 19. http://www.examiner.com/article/ca-farmer-warns-don-t-trust-oilindustry-state-or-courts-to-protect-water.

Anonymous. (2012), "Fracking and the Food System", Food \& Water Watch, June.8. http:// www foodandwaterwatch.org.

Benusic, M. (2013), "Fracking in BC: A public health concern", BC Medical Journal, Vol. 55 No. 5, June, pp. $238-239$.

Bullis, K. (2013), "One Way to Solve Fracking's Dirty Problem", MIT Technology Review, September 24. bttp:/ / wmw.technologyreview.com/ news/519416/ one-way-to-solve-frackings-dirty-problem/

Carroll, J. (2011), "Water Is the New Texas Liquid Gold”, BusinessWeek, 16 June. http://www.businessweek.com/magazine/content/11 26/b4234028472314.htm

Cohen, T. (2014), "Fracking must start by end of year, says Cameron: PM wants Britain to reduce dependence on Russian gas," Daily Mail Online, 25 March.

http://www.dailymail.co.uk/news/article-2589417/Fracking-start-end-year-says-Cameron-PMwants-Britain-reduce-dependence-Russian-gas.html

Drejam, M. (2012), "Pennsylvania Fracking Can Put Water at Risk, Duke Study Finds", BusinessWeek, 10 July. $\quad$ http://www.businessweek.com/news/2012-07-09/pennsylvania-fracking-can-put-watersources-at-risk-study-finds

Galbraith, K. (2013), “As Fracking Increases, So Do Fears About Water Supply”, The Texas Tribune, 7 March.http://www.nytimes.com/2013/03/08/us/as-fracking-in-texas-increases-so-do-watersupply-fears.html

Grossi, M. (2013), "Fracking probe extends in Central Valley", Fresno Bee, 2 November. http:// www.fresnobee.com/2013/11/02/3587611/fracking-probe-expands-in-valley.btml

Healy, J. (2013), "After the Floods in Colorado, a Deluge of Worry About Leaking Oil", The New York Times, 27 September, p. 12.

Hubbard, B. (2010), "Millions of gallons spilled in Colo. over 21/2 year period", The Denver Post, 28 June. http://www.denverpost.com/ci 15391192

Lafrance, D. (2011), "Nothing Should Trump a Clean Water Future", American Water Works Association Journal, Vol. 103, No. 9, pp. 6 - 7.

McElroy, M. and Lu, X. (2013), "Fracking's Future. Natural gas, the economy, and America's energy prospects", Harvard Magazine, January-February, pp. $24-27$.

McKinley, J. (2013), "Fracking Fight Focuses on a New York Town's Ban", The New York Times, 23 October. http://www.nytimes.com/2013/10/24/nyregion/court-case-on-fracking-ban-indryden-ny-may-have-wide-implications.html

Richardson, V. (2013), "Pro-frackers try to stem leak claims; Oil spillage from floods small by comparison to Exxon Valdez disaster", The Washington Times, 26September, p. 7. 
Royte, E. (2012), "Fracking Our Food Supply", The Nation, 17December. http://www.thenation.com/article/171504/fracking-our-food-supply

Schaefer, K. (2012), "Fracking and Water: A New Way To Profit from the Industry's Biggest Problem", The Oil \& Gas Investments Bulletin, 14 February. http://oilprice.com/Energy/EnergyGeneral/Fracking-and-Water-A-New-Way-To-Profit-from-the-Industrys-Biggest-Problem.html

Schmidt, C. (2013), "Estimating Wastewater Impacts from Fracking”, Environmental Health Perspectives, Vol. 121 No.4, April, pp. A117 - A121.

Smith, T. (2012), "Environmental Considerations of Shale Gas Development", Chemical Engineering Progress, Vol. 108 No.8, pp. 53 - 59 .

Thompson, D. (2013), “Contaminated Home Wells Found near Pa. Fracking Site: Study", US News \& World Report, 24June.http://health.usnews.com/health-news/news/articles/2013/06/24/contaminatedhome-wells-found-near-pa-fracking-site-study 
